\title{
Optimization of Agave tequilana Weber var. Azul Juice Spray Drying Process
}

\author{
Alejandra Chávez-Rodríguez, ${ }^{1}$ Irma G. López-Muraira, ${ }^{1}$ Juan F. Goméz-Leyva, \\ Guadalupe Luna-Solano, ${ }^{2}$ Rosa I. Ortíz-Basurto, ${ }^{3}$ and Isaac Andrade-González ${ }^{1}$ \\ ${ }^{1}$ Departamento de Estudios de Postgrado e Investigación (DEPI), Instituto Tecnológico de Tlajomulco, \\ Km 10 Carr, San Miguel Cuyutlan, CP 45640, Tlajomulco de Zúñiga, JAL, Mexico \\ ${ }^{2}$ DEPI, Instituto Tecnológico de Orizaba, Avenida Oriente 9 No. 852, Colonia Emiliano Zapata, \\ CP 94320, Orizaba, VER, Mexico \\ ${ }^{3}$ DEPI, Instituto Tecnológico de Tepic, Avenida Tecnológico No. 2595, Colonia Lagos del Country, \\ CP 63175, Tepic, NAY, Mexico
}

Correspondence should be addressed to Isaac Andrade-González; isaacag2001@yahoo.com.mx

Received 21 August 2013; Revised 15 November 2013; Accepted 15 November 2013; Published 29 January 2014

Academic Editor: Souhail Besbes

Copyright ( 2014 Alejandra Chávez-Rodríguez et al. This is an open access article distributed under the Creative Commons Attribution License, which permits unrestricted use, distribution, and reproduction in any medium, provided the original work is properly cited.

\begin{abstract}
In this work, the response surface methodology was employed to optimize the microencapsulation of Agave tequilana Weber var. azul juice with whey protein isolated using a spray drying technique. A Box-Behnken design was used to establish optimum spray drying conditions for Agave tequilana juice. The process was optimized to obtain maximum powder yield with the best solubility time, hygroscopicity, bulk density, water activity, and reducing sugars. The independent parameters for the spray drying process were outlet temperature of $70-80^{\circ} \mathrm{C}$, atomizer speed of $20000-30000 \mathrm{rpm}$, and airflow of $0.20-0.23 \mathrm{~m}^{3} \mathrm{~s}^{-1}$. The best spray drying condition was at outlet temperature of $80^{\circ} \mathrm{C}$, atomizer speed of $20000 \mathrm{rpm}$, and air flow rate of $0.23 \mathrm{~m}^{3} \mathrm{~s}^{-1}$ to obtain maximum powder yield $(14.65 \% \mathrm{bm})$, minimum solubility time $(352.8 \mathrm{~s})$, maximum bulk density $\left(560 \mathrm{~kg} \mathrm{~m}^{-3}\right)$, minimum hygroscopicity $(1.9 \times$ $10^{-7} \mathrm{~kg}_{\text {water }} \mathrm{s}^{-1}$ ), and minimum $a_{w}(0.39)$. The Agave tequilana powder may be considered as an interesting source of dietary fiber used as food additive in food and nutraceutical industries.
\end{abstract}

\section{Introduction}

Agave tequilana Weber var. azul is an important crop in the state of Jalisco, México, for tequila production. Today, Agave juice is also used to make syrup and fructooligosaccharides (FOS) powder as another alternative industrial due to its high content of fructans. These Agave fructans consist of a complex mixture of FOS containing principally $\beta(2-1)$ and $\beta(2-6)$ linkages $[1,2]$, which can stimulate the growth of bifidobacteria as prebiotic, increase $\mathrm{Ca}^{++}$absorption, and decrease blood triglyceride levels [3-6]. The prebiotic effect opens the new alternatives for Agave fructans as food ingredients: sweeteners, texture modifiers, and fat-replacer in food products [7]. Also, FOS are officially recognized as natural food ingredients and are classified as dietary fibers. However, the FOS are carbohydrates that undergo many changes, like the hydrolysis, Maillard-reaction, and caramelization [3].

Spray drying is one of the most important methods for obtaining powders. Although the spray drying is a fast process, changes on the spray drying conditions can affect the physicochemical and functional proprieties. For example, the spray drying of chicory inulin at a temperature range of 135$195^{\circ} \mathrm{C}$ resulted in significant FOS degradation (20 to $\left.100 \%\right)$ and loss of its functional properties because the heat induced degradation [8, 9]. Microencapsulation of FOS in a carrier is an alternative technique that can be used to minimize degradation and loss of functional properties during spray drying $[10,11]$. Spray drying is the most commonly used encapsulation method in the food industry [11] and exist carriers for several spray-dried products $[12,13]$. The influence 
of the main process variables, such as temperature, atomizer speed, air flow, feed flow, nature of food and its geometry, carriers types, and solution to sample ratio on the mass transfer mechanism, has been studied extensively [14-18].

Response Surface Methodology (RSM) will be a useful tool to obtain successful spray drying operating parameter, because RSM describes the effect of the test variables on the responses, determines interrelationships among test variables, and represents the combined effect of all test variables on the response $[19,20]$. Moreover we studied out the effects of feed properties and drying conditions on the physical properties of the powder, like moisture content, bulk density, hygroscopicity, solubility time, and flow behavior. We found that inlet air temperature and feed flow rate are the significant parameters in case of most of the responses analyzed by [19]. It was found that the air temperature and airflow rate are the important parameters in case of most of the responses on ginger extract spray drying [21]. We found that the best drying conditions for the inulin were: $210^{\circ} \mathrm{C}$ and $5 \%$ and powder particles presented spherical and smooth surfaces [22].

Although the best drying conditions for inulin or FOS were reported by [22], additional work is needed to determine the optimal processing parameters to spray dry Agave juice. The purpose of this work was to optimize the spray drying process on physicochemical properties of Agave tequilana Weber var. azul fructooligosaccharides.

\section{Materials and Methods}

Seven-year-old Agave tequilana Weber var. azul "pine" and "head" were harvested and processed (washed, squeezed, and filtrated by Agaveros Industriales of Jalisco in Jocotepec, Jalisco, Mexico) to obtain the juice, which was kept at $-20^{\circ} \mathrm{C}$.

2.1. Spray Drying. A pilot scale spray dryer (GEA NIRO model A/S Production minor, Columbia, Washington, D.C., USA) with a cylindrical section of the drying chamber that is $1.2 \mathrm{~m}$ in diameter and $1 \mathrm{~m}$ high and the conical section that is $0.7 \mathrm{~m}$ high with a bottom outlet that is $0.3 \mathrm{~m}$ in diameter. The rotating disc atomizer has twenty-four annular $4 \times 3 \mathrm{~mm}$ orifices on an $18 \mathrm{~mm}$ thick disc with a diameter of $0.10 \mathrm{~m}$. The atomizer has the capacity to evaporate $40 \mathrm{~kg}$ of water per hour and was used for the drying process in all experimental treatment. The outlet temperature, atomizer speed, and airflow were set to 70 and $80^{\circ} \mathrm{C}, 20000$ and $30000 \mathrm{rpm}$, and 0.20 and $0.23 \mathrm{~m}^{3} \mathrm{~s}^{-1}$.

In each treatment, the Agave juice was defreezed at $4^{\circ} \mathrm{C}$, concentrated at $20^{\circ} \mathrm{Brix}$, and mixed with $0.1 \%$ commercial whey protein isolated WPC-80 (donated by America Alimentos Company). The juice mixture was homogenized using a mixer (Glas-Col Mod. Precision Stirrer, IN, USA).

The juice-whey protein isolated mixture was placed into a stainless steel container. A plastic flexible hose was placed inside the container and connected to the inlet of a variable flow peristaltic pump (Watson Marlon, Model 504U, Falmouth, Cornwall, UK). The pump outlet was then connected to the feed hose of the atomizer. The drying time in all treatments was $45 \mathrm{~min}$.

The spray-dried powders were collected, weighed, and packed in $4 \mathrm{~L}$ glass flasks.

2.2. Bulk Density and Solubility Time. The total of $20 \pm 0.1 \mathrm{~g}$ of powder was transferred into a $100 \mathrm{~mL}$ graduated cylinder and gently dropped onto a rubber mat from a height of $0.15 \mathrm{~m}$ for 40 times. The bulk density was calculated by dividing the powder weight by the volume it occupied in the cylinder; samples were run in duplicate [23-26].

The spray-dried powder solubility time was determined as described by [26]. Briefly, $10 \pm 0.1 \mathrm{~g}$ of powder was added to $250 \mathrm{~mL}$ distilled water at $25^{\circ} \mathrm{C}$. The mixture was then agitated on a stirring hot plate (Cimarec, Model SP131015, Thermo Scientific, San Jose, CA, United States) set at position $350 \mathrm{rpm}$ and the time required for the material to completely dissolve was recorded. All samples were run in duplicate.

2.3. Hygroscopicity. The total of $1 \pm 0.01 \mathrm{~g}$ of powder was evenly spread on a glass dish ( $0.09 \mathrm{~m}$ diameter) with a high humid air-to-powder surface area ratio. Samples were then placed in desiccators set at $25^{\circ} \mathrm{C}$ and $85 \%$ relative humidity using an $\mathrm{HNO}_{3}$ solution. A 90 min sampling interval was selected to obtain the moisture sorption kinetics. The weight gain of the samples was considerably lower after $90 \mathrm{~min}$ [23]. Thus, the weight increase per gram of powder solids after 90 min was determined $[23,26]$. All samples were run in duplicate.

2.4. Water Activity. The water activity of Agave juice powders was measured at $25^{\circ} \mathrm{C}$ using an Aqualab 3TE (Decagon, Pullman, WA, USA) calibrated with a $\mathrm{LiCl}$ solution with known water activity. All samples were run in duplicate.

2.5. Yield. The Agave juice yield of all experiments was determined. The mass of product was divided by the product of the total mass of solution dried during each experiment $(8.224 \mathrm{~kg})$ and the total solids concentration. The average and range of yields for a particular set of operating conditions were then calculated from the three repeat experiments. To estimate the yield and for further spray-drying analysis, only the powder collected from the sample pot was considered.

2.6. Total Reducing Sugars. Direct reducing sugars were measured by the Fehling method modified [27], without hydrolysis. All samples were run in duplicate.

2.7. Experimental Design and Optimization. The effects of the three independent processing parameters, outlet temperature $\left(\mathrm{X} 1,{ }^{\circ} \mathrm{C}\right)$, atomizer speed $(\mathrm{X} 2, \mathrm{rpm})$, and airflow $\left(\mathrm{X} 3, \mathrm{~m}^{3} \mathrm{~s}^{-1}\right)$ on the dependent variables were investigated; the response surface methodology is presented in Table 1. Box-Behnken designs are response surface designs requiring only three levels, which are coded as $-1,0$, and +1 . A total of 17 experiments in this study were based on three levels and the three-factor experimental design, with three replicates at the centre of 
TABLE 1: Box-Behnken experimental design.

\begin{tabular}{|c|c|c|c|c|}
\hline \multirow{2}{*}{ Std. order } & \multirow{2}{*}{ Run order } & \multicolumn{3}{|c|}{ Independent variables } \\
\hline & & Temperature $\left({ }^{\circ} \mathrm{C}\right)$ & Atomizer speed (rpm) & Air flow $\left(\mathrm{ms}^{-1}\right)$ \\
\hline 2 & 1 & $80(+1)$ & $20,000(-1)$ & $23(0)$ \\
\hline 14 & 2 & $75(0)$ & $25,000(0)$ & $23(0)$ \\
\hline 8 & 3 & $80(+1)$ & $25,000(0)$ & $24(+1)$ \\
\hline 1 & 4 & $70(-1)$ & $20,000(-1)$ & $23(0)$ \\
\hline 15 & 5 & $75(0)$ & $25,000(0)$ & $23(0)$ \\
\hline 9 & 6 & $75(0)$ & $20,000(-1)$ & $22(-1)$ \\
\hline 4 & 7 & $80(+1)$ & $30,000(+1)$ & $23(0)$ \\
\hline 7 & 8 & $70(-1)$ & $25,000(0)$ & $24(+1)$ \\
\hline 13 & 9 & $75(0)$ & $25,000(0)$ & $23(0)$ \\
\hline 10 & 10 & $75(0)$ & $30,000(+1)$ & $22(-1)$ \\
\hline 11 & 11 & $75(0)$ & $20,000(-1)$ & $24(+1)$ \\
\hline 3 & 12 & $70(-1)$ & $30,000(+1)$ & $23(0)$ \\
\hline 6 & 13 & $80(+1)$ & $25,000(0)$ & $22(-1)$ \\
\hline 12 & 14 & $75(0)$ & $30,000(+1)$ & $24(+1)$ \\
\hline 5 & 15 & $70(-1)$ & $25,000(0)$ & $22(-1)$ \\
\hline
\end{tabular}

Values in parentheses () indicate coded levels.

the design to estimate the pure error sum of squares. The statistical software MINITAB (Release 14.1) was used for the experimental design, data analysis, and regression modeling. The independent variables were $\mathrm{X} 1\left(70-80^{\circ} \mathrm{C}\right), \mathrm{X} 2(20,000-$ $30,000 \mathrm{rpm})$, and $\mathrm{X} 3\left(0.20-0.23 \mathrm{~m}^{3} \mathrm{~s}^{-1}\right)$ with point center at $75^{\circ} \mathrm{C}, 25000 \mathrm{rpm}$, and $0.215 \mathrm{~m}^{3} \mathrm{~s}^{-1}$, respectively. The experimental order was randomized. Experimental data from the Box-Behnken design was analyzed and fitted to a secondorder polynomial model. Consider

$$
Y_{k}=\beta_{0}+\sum_{i=1}^{2} \beta_{i} X_{i}+\sum_{i=1}^{2} \beta_{i i} X_{i}^{2}+\sum_{i} \sum_{j=i+1} \beta_{i j} X_{i} X_{j}
$$

where $Y_{k}$ is the predicted response, $\beta_{0}$ is the constant (intercept), $\beta_{i}$ is the linear coefficient, $\beta_{i i}$ is the quadratic coefficient, and $\beta_{i j}$ is the cross-product coefficient. $X_{i}$ and $X_{j}$ are independent variables.

\section{Results and Discussion}

3.1. Fitted Models and Response Surfaces. Results of the experimental design with standard deviation to quality parameters of Agave juice subjected to different spray drying conditions are shown in Table 2. The regression coefficients $(\beta)$ of the quadratic polynomial equation for the coded independent variables, interactions upon response variables, determination coefficient, and lack-of-fit test and probability are shown in Table 3 for all the responses. The significant terms $(P \leq$ 0.05 ) were used as a tool to check the significance of each of the coefficients of the proposed models for each response.

Analysis of variance showed that the quadratic polynomial models were highly significant $(P \leq 0.001)$ for solubility (Y5) and yield (Y6) and less significant for bulk density (Y2), activity water (Y1), hygroscopicity (Y3), and reduced sugar $(\mathrm{Y} 4)$. The coefficients of determination (R2) values for the response variables Y6 and Y5 were greater at 0.99 and 0.98 , respectively; for variable $\mathrm{Y} 2$, the coefficient was 0.82 ; and for variables $\mathrm{Y} 4, \mathrm{Y} 3$, and $\mathrm{Y} 1$, the coefficients ranged from 0.66 to 0.59 . The coefficients of variation (CV) should not be greater than $10 \%$, but in this work, they were found in the range of $0.026-4.72 \%$ for all the responses, which indicates better precision and reliability of the experiments carried out. The lack-of-fit, which measures the fitness of the models, resulted in a significant $F$-value only for solubility and yield, indicating that these models were sufficiently accurate for predicting those responses. The $P$ values of the models were 0.0001 for yield, 0.001 for solubility, 0.16 for bulk density, 0.558 for hygroscopicity, 0.484 for reduced sugar, and 0.638 for water activity, which further indicates the goodness of fit.

3.2. Response Surface Analysis of Powder Yield. Using multiple regression techniques, a response surface model was developed for powder yield as a function of the spray drying process variables. A complete-second order model (1) was tested for its ability to describe the response surface. The analysis of variance (Table 3 ) shows that the model is highly significant $(P<0.0001)$. Values of $P$ less than 0.05 indicate that the model terms are significant. In this case, $\beta_{2}, \beta_{3}, \beta_{1}^{2}$, $\beta_{2}^{2}, \beta_{3}^{2}, \beta_{12}, \beta_{13}$, and $\beta_{23}$ are significant model terms. Values greater than 0.10 indicate that the model terms are not significant. The lack-of-fit $P$ value of 0.029 implies that the lack-of-fit is highly significant. Thus, all of the quadratic terms are significant.

The powder yield varied in the range from $24.85 \%$ to $76.70 \%$, in our experiment runs. The quadratic polynomial model was used to fit the quadratic model for this response with $R 2=0.990$. The ANOVA analysis for the response "powder yield" showed that atomizer speed and airflow are more significant than outlet temperature. However, in two representative plots are shown the effects of outlet 


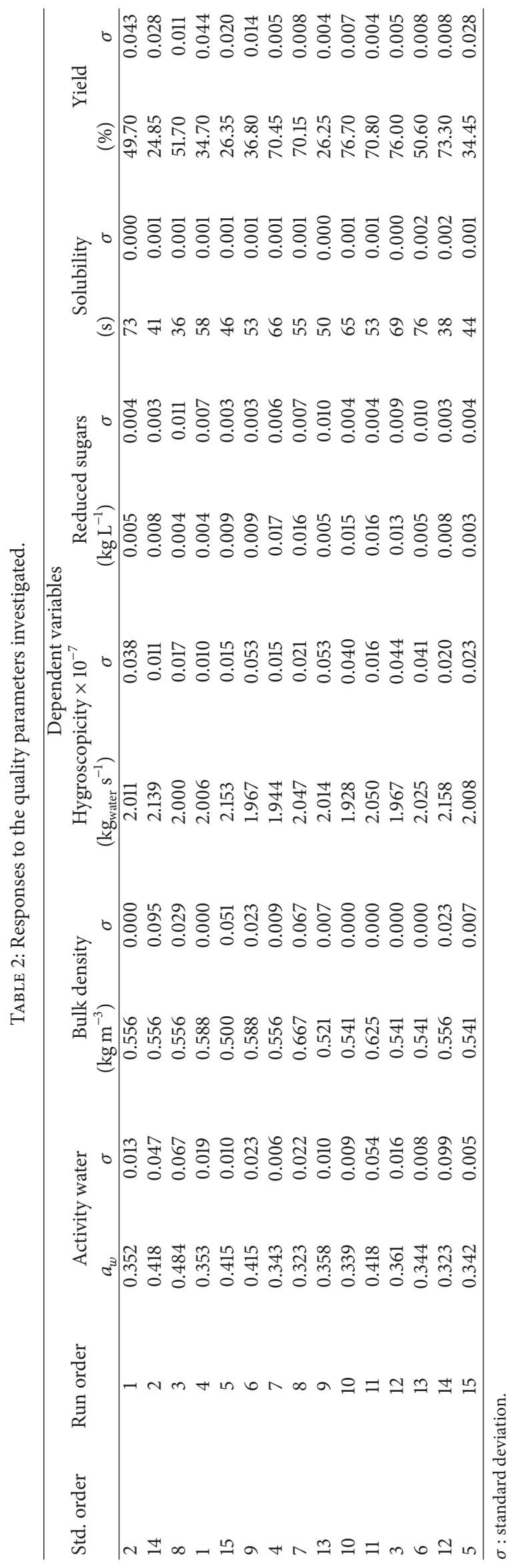




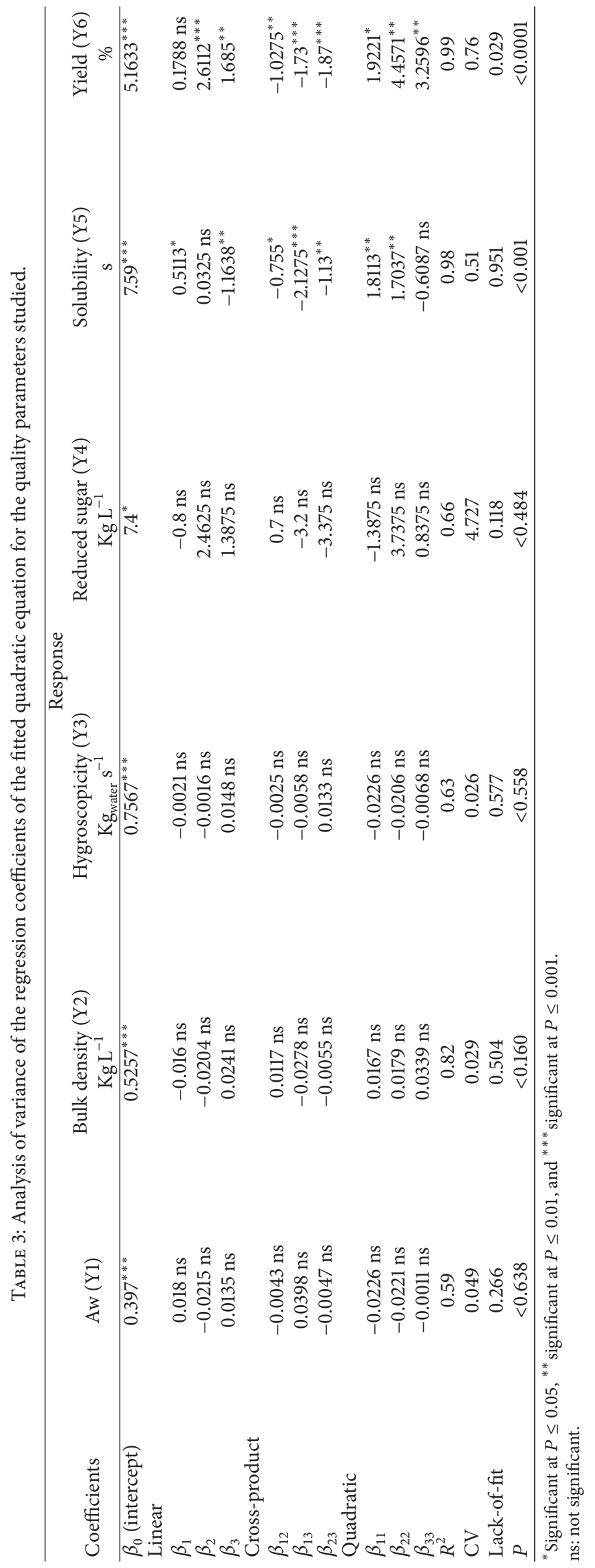




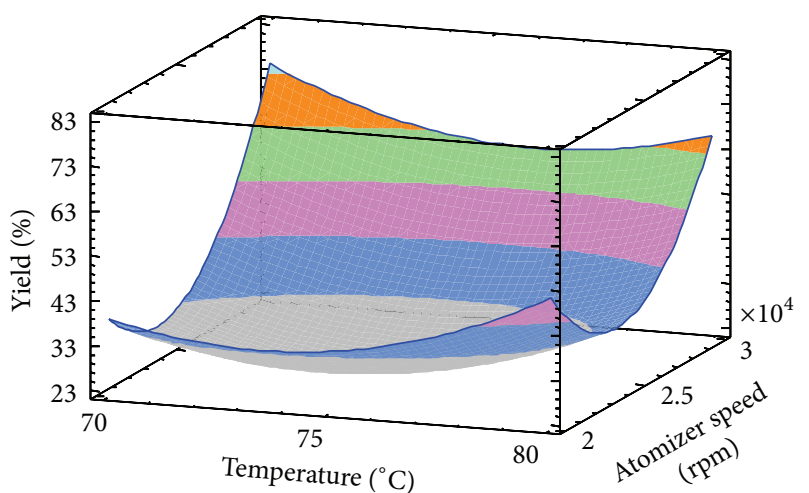

Yield

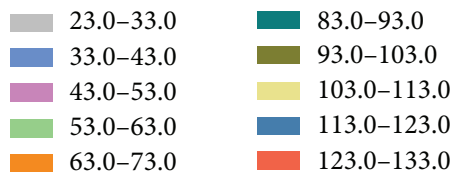

(a)

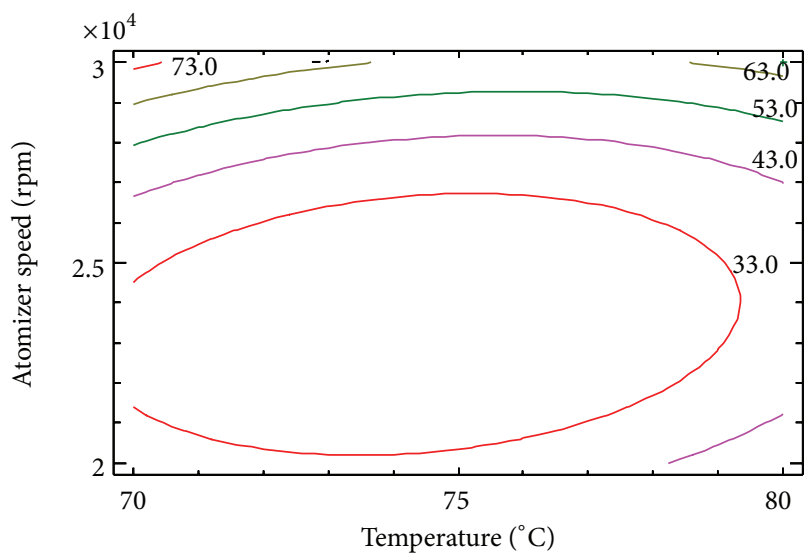

Yield

$\begin{array}{rr}23.0 & -\quad 93.0 \\ -33.0 & -103.0 \\ -43.0 & 113.0 \\ 53.0 & -\quad 123.0 \\ 63.0 & -133.0 \\ -73.0 & -143.0\end{array}$

(c)

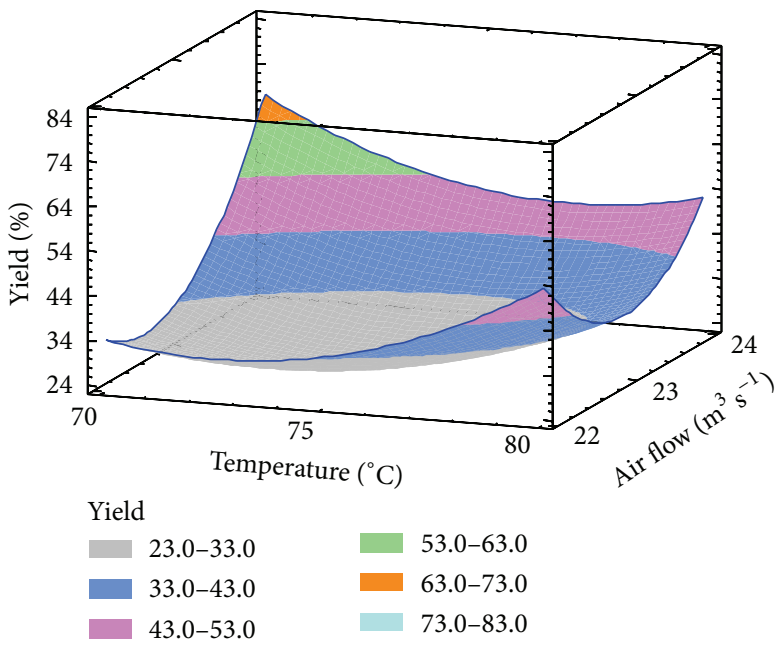

(b)

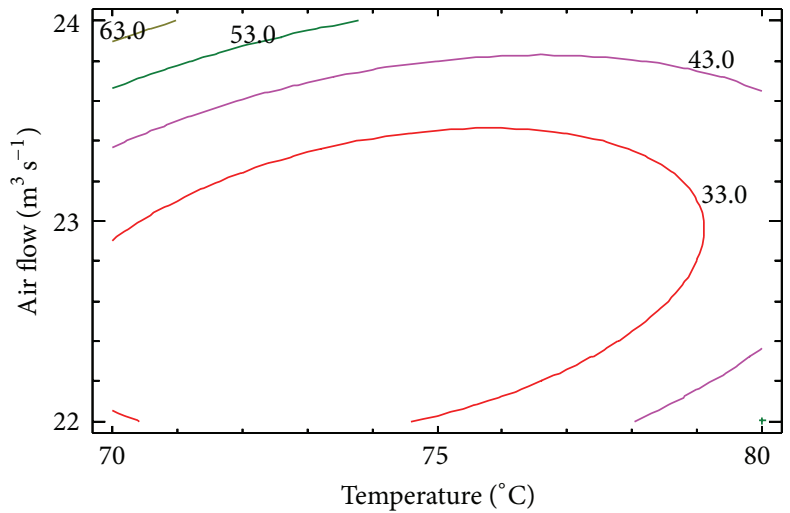

Yield

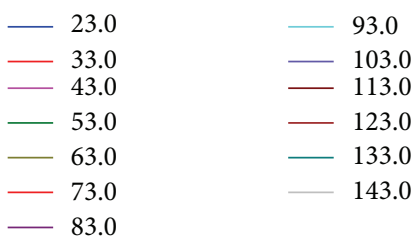

(d)

FIGURE 1: Surface plot showing (a) the effect of temperature and atomizer speed at air flow $0.215 \mathrm{~m}^{3} \mathrm{~s}^{-1}$ and (b) the effect of temperature and air flow at an atomizer speed of $25000 \mathrm{rpm}$ on the powder yield.

temperature with atomizer speed and airflow (Figures 1(a) and 1(b)). Figure 1(a) shows the effect of temperature and atomizer speed on powder yield at the airflow center point (0) and Figure 1(b) shows the effect of outlet temperature and airflow. In Figure 1(a) it is evident that at lower outlet temperatures and higher atomizer speeds the powder yield presents the higher value. Evenly in Figure 1(b) we can also observe that at lower outlet temperature and higher airflow the powder yield presents the higher value. Even if the inlet temperature was constant in all experiments $\left(180^{\circ} \mathrm{C}\right)$, the increase of feed flow due to control of the outlet temperature and the nature amorphous of spray-dried material causes significant problems with the deposition of powder on the wall of spray dryer, which reduces the powder yield $[19,22]$.

3.3. Response Surface Analysis of Solubility Time. Using multiple regression techniques, a response surface model for the powder solubility time, as a function of spray drying process variables, was developed. A complete second-order model 

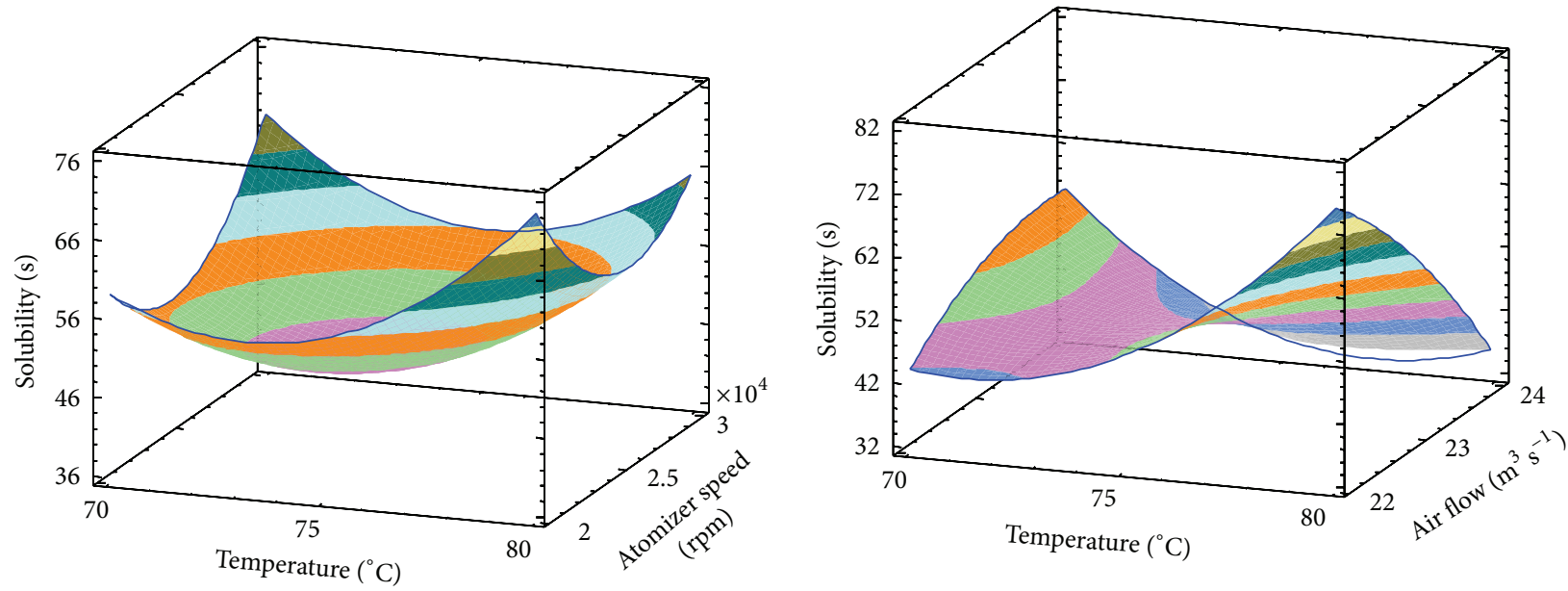

Solubility

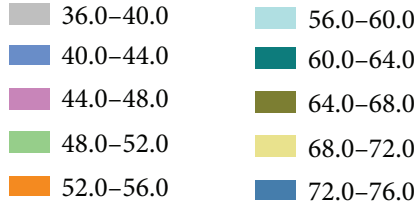

(a)

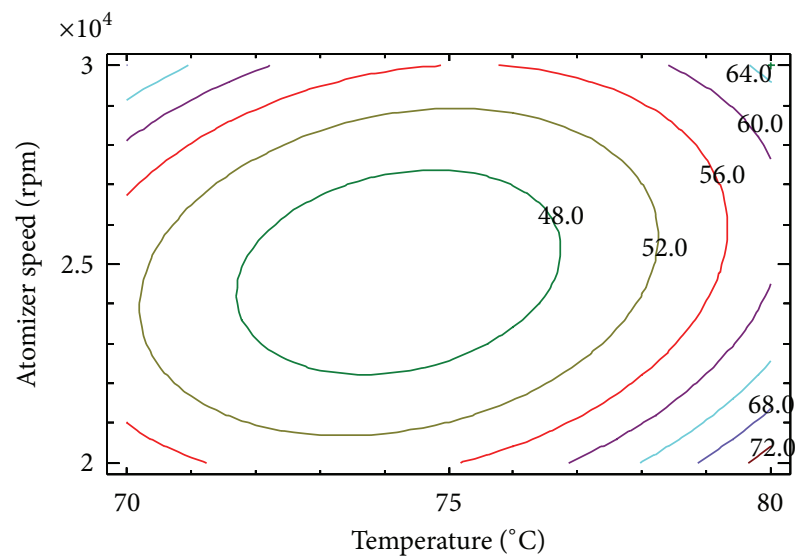

Solubility

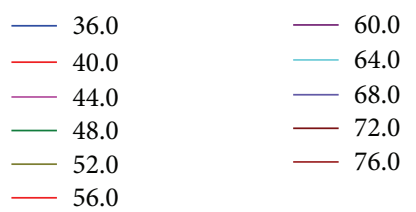

(c)

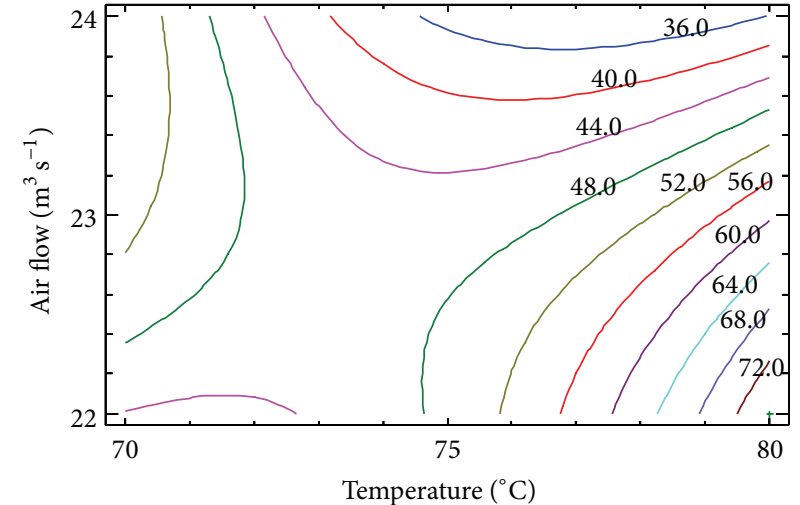

Solubility

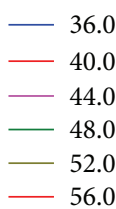

(d)

FiguRE 2: Surface plot showing (a) the effect of temperature and atomizer speed at an air flow of $0.215 \mathrm{~m}^{3} \mathrm{~s}^{-1}$ and (b) the effect of temperature and air flow at an atomizer speed of $25000 \mathrm{rpm}$ on the powder solubility time.

(1) was tested for its ability to describe the response surface. Analysis of variance (Table 2) shows that the model is highly significant $(P<0.001)$. Values of $P$ less than 0.0500 indicate that the model terms are significant. In this case, $\beta_{0}, \beta_{1}$, $\beta_{3}, \beta_{1}^{2}, \beta_{2}^{2}, \beta_{12}, \beta_{13}$, and $\beta_{23}$ are significant model terms. Values greater than 0.1000 indicate that the model terms are not significant. The lack-of-fit $P$ value of 0.951 implies that the lack-of-fit is slightly significant. However, the determination coefficient was at 0.98 .

Figures 2(a) and 2(b) present the surface and contour plots for solubility. Figure 2(a) shows the effect of temperature and atomizer speed at the airflow centre point $\left(0.200 \mathrm{~m}^{3} \mathrm{~s}^{-1}\right)$ on powder solubility. It is evident from Figure 2(a) that the solubility showed an increase with an increase in outlet 


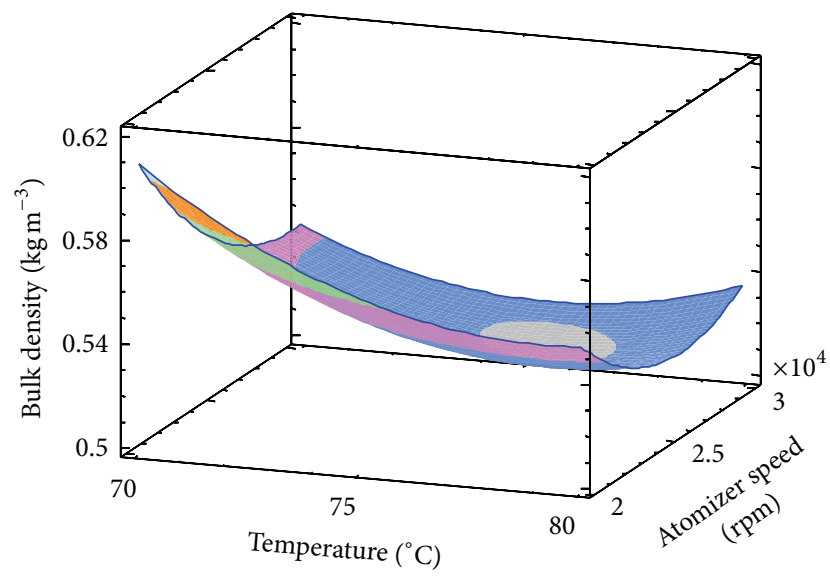

Bulk density

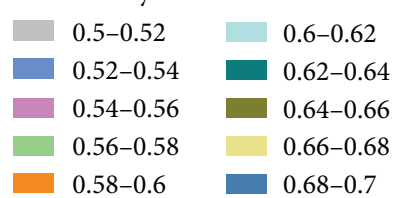

(a)

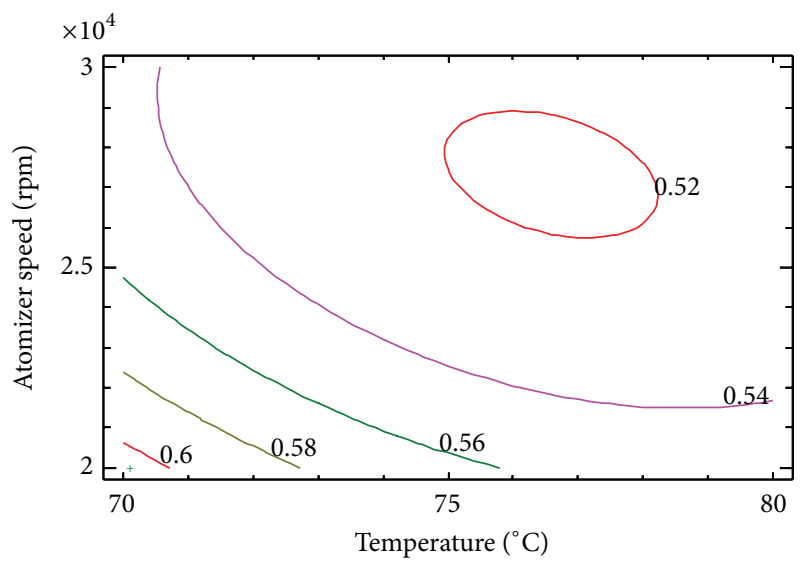

Bulk density

$\begin{array}{ll}-0.5 & -0.62 \\ -0.52 & -0.64 \\ -0.54 & -0.66 \\ -0.56 & -0.68 \\ 0.58 & -0.7 \\ 0.6 & \end{array}$

(c)
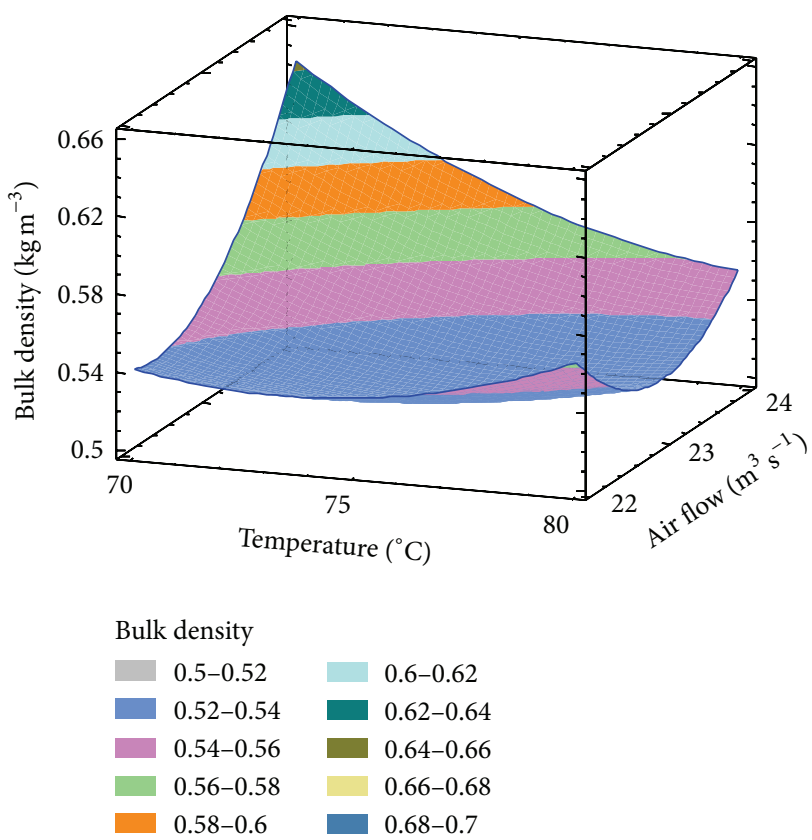

(b)

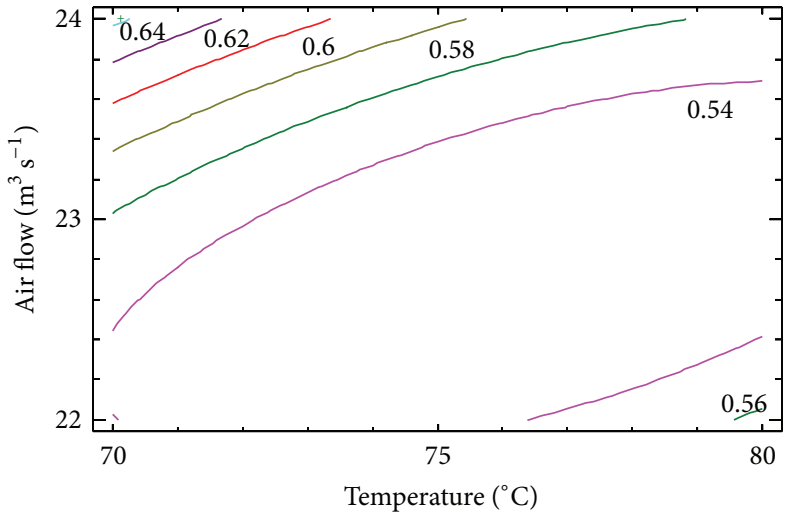

Bulk density

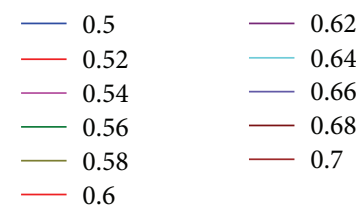

(d)

Figure 3: Surface plot showing (a) the effect of temperature and atomizer speed at an air flow of $0.215 \mathrm{~m}^{3} \mathrm{~s}^{-1}$ and (b) the effect of temperature and air flow at an atomizer speed of $25000 \mathrm{rpm}$ on the bulk density.

temperature and atomizer speed. However, at the centre point, the solubility decreases to a lower value at $38 \mathrm{~s}$. Figure 2(b) shows that with an increase in outlet temperatures the solubility is also increased, but an increase in airflows represents a decrease in the solubility. This trend is similar to that reported by other works $[24,26]$.

3.4. Response Surface Analysis of Bulk Density. A surface response model was also developed for bulk density as a function of the spray drying process variables. A complete second-order model (1) was tested for its ability to describe the response surface. Analysis of variance (Table 2) showed that the model was not significant $(P<0.05)$. In this case only $\beta_{0}$ was significant. Values greater than 0.1000 indicate that the model terms are not significant. The lack-of-fit $P$ value of 0.504 implies that it is not significant. Thus, it means that none of the quadratic terms were significant. However, the determination coefficient was at 0.82 . 
Figures 3(a) and 3(b) show the surface and contour plots for bulk density. Figure 3(a) shows the effect of temperature and atomizer speed at the airflow centre point $\left(0.200 \mathrm{~m}^{3} \mathrm{~s}^{-1}\right)$ on bulk density. It is evident from Figure 3(a) that, at lower level of outlet temperatures and atomizer speed, the bulk density reaches the highest value, as well as higher level of airflow and low level of outlet temperature (Figure 3(b)). In Figures 3(a) and 3(b), the bulk density has deceased with the increase of the outlet temperature due to an increase in the feed flow caused by outlet temperature control in each experiment $[21,26]$. This same behavior was observed for hygroscopicity, water activity, and reducing sugars.

3.5. Optimization of Spray Drying Conditions. The spray drying process was optimized to the responses using a numerical optimization technique in which an equal importance of "one" was given to all three process parameters (temperature, atomizer speed, and airflow). The process was optimized to maximize powder yield, solubility, and bulk density and to minimize hygroscopicity and water activity. As a result of, the optimum operating conditions for temperature, atomizer speed, and airflow were $80^{\circ} \mathrm{C}, 20,000 \mathrm{rpm}$, and $0.230 \mathrm{~m}^{3} \mathrm{~s}^{-1}$, respectively. The solution for the optimum spray drying conditions was found to satisfy the goal with a powder Yield same at $73.3 \% \mathrm{w} / \mathrm{w}$, solubility at $35.28 \mathrm{~s}$, hygroscopicity at $1.9 \times 10^{-7} \mathrm{~kg}_{\text {water }} \mathrm{s}^{-1}$, bulk density at $560 \mathrm{~kg} \mathrm{~m}^{-3}$, and water activity (aw) at 0.39 .

\section{Conclusions}

The responses were correlated with independent variables using proper transformations of the responses, and the data points were fitted in a quadratic model with significant values of R2. Spray drying of Agave tequilana juice regardless of outlet temperature, atomizer speed, and air flow did not cause a significant difference in hygroscopicity, bulk density, water activity, and reduced sugar. However, significant effects were observed for powder yield and solubility at low or high temperatures, atomizer speeds, or airflows. Spray drying of Agave juice at low outlet temperatures $\left(70^{\circ} \mathrm{C}\right)$ enhanced the cloud value with a maximum powder yield. The optimization of the drying process showed that the best conditions for pilot spray drying are inlet drying temperature of $180^{\circ} \mathrm{C}$ and outlet drying temperature of $80^{\circ} \mathrm{C}$ associated with an atomizer speed of $20,000 \mathrm{rpm}$ and an airflow of $0.23 \mathrm{~m}^{3} \mathrm{~s}^{-1}$, maintaining the material at room temperature $\left(25^{\circ} \mathrm{C}\right)$ during the feeding of the dryer. Optimization of responses was based on minimum values of water activity and hygroscopicity and maximum values of yield, solubility, and bulk density.

\section{Nomenclature}

$Y$ : Predicted response

$X$ : Independent variables.

Greek Letters

$\beta_{0}$ : Constant (intercept)

$\beta_{i}$ : Linear coefficient

$\beta_{i i}$ : Quadratic coefficient

$\beta_{i j}$ : Cross-product coefficient.
Subscripts

$i$ : Number of independent variables.

\section{Conflict of Interests}

The authors declare that there is no conflict of interests regarding the publication of this paper.

\section{Acknowledgments}

The authors would like to thank Agaveros Industriales de Jalisco, S. P. R. de R. L., for providing the Agave tequilana juice samples. They would like to thank America Alimentos, S. A. de C. V., for providing the whey protein isolated.

\section{References}

[1] M. G. López, N. A. Mancilla-Margalli, and G. Mendoza-Diaz, "Molecular Structures of Fructans from Agave tequilana Weber var. azul," Journal of Agricultural and Food Chemistry, vol. 51, no. 27, pp. 7835-7840, 2003.

[2] N. A. Mancilla-Margalli and M. G. Lopez, "Water-soluble carbohydrates and fructan structure patterns from Agave and Dasylirion species," Journal of Agricultural and Food Chemistry, vol. 54, no. 20, pp. 7832-7839, 2006.

[3] A. Matusek, P. Merész, T. K. Diem-Le, and F. Örsi, "Effect of temperature and $\mathrm{pH}$ on the degradation of fructo-oligosaccharides," European Food Research and Technology, vol. 228, no. 3, pp. 355-365, 2009.

[4] J. E. Urías-Silvas, P. D. Cani, E. Delmée, A. Neyrinck, M. G. López, and N. M. Delzenne, "Physiological effects of dietary fructans extracted from Agave tequilana Gto. and Dasylirion spp," British Journal of Nutrition, vol. 99, no. 2, pp. 254-261, 2008.

[5] P. D. Cani, C. Dewever, and N. M. Delzenne, "Inulin-type fructans modulate gastrointestinal peptides involved in appetite regulation (glucagon-like peptide-1 and ghrelin) in rats," British Journal of Nutrition, vol. 92, no. 3, pp. 521-526, 2004.

[6] M. Chandalia, A. Garg, D. Lutjohann, K. von Bergmann, S. M. Grundy, and L. J. Brinkley, "Beneficial effects of high dietary fiber intake in patients with type 2 diabetes mellitus," The New England Journal of Medicine, vol. 342, no. 19, pp. 1392-1398, 2000.

[7] A. Ávila-Fernández, N. Galicia-Lagunas, M. E. RodríguezAlegría, C. Olvera, and A. López-Munguía, "Production of functional oligosaccharides through limited acid hydrolysis of agave fructans," Food Chemistry, vol. 129, no. 2-15, pp. 380-386.

[8] A. Böhm, I. Kaiser, A. Trebstein, and T. Henle, "Heat-induced degradation of inulin," European Food Research and Technology, vol. 220, no. 5-6, pp. 466-471, 2005.

[9] J. Huebner, R. L. Wehling, A. Parkhurst, and R. W. Hutkins, "Effect of processing conditions on the prebiotic activity of commercial prebiotics," International Dairy Journal, vol. 18, no. 3, pp. 287-293, 2008.

[10] T. A. G. Langrish and S. Wang, "Crystallization rates for amorphous sucrose and lactose powders from spray drying: a comparison," Drying Technology, vol. 27, no. 4, pp. 606-614, 2009.

[11] Ö. A. Bayram, M. Bayram, and A. R. Tekin, "Whey powder as a carrier in spray drying of sumac concentrate," Journal of Food Process Engineering, vol. 31, no. 1, pp. 105-119, 2008. 
[12] L. Szente and J. Szejtli, "Molecular encapsulation of natural and synthetic coffee flavour with b-cyclodextrin," Journal of Food Science, no. 5, pp. 1024-1026, 1986.

[13] R. Zilberboim, I. J. Kopelman, and Y. Talmon, "Microencapsulation by a dehydrating liquid: retention of paprika oleoresin and aromatic esters," Journal of Food Science, vol. 51, no. 5, pp. 13011306, 1986.

[14] S. Gonzalez-Palomares, M. Estarrón-Espinosa, J. F. GómezLeyva, and I. Andrade-González, "Effect of the temperature on the spray drying of Roselle extracts (Hibiscus sabdariffa L.)," Plant Foods for Human Nutrition, vol. 64, no. 1, pp. 62-67, 2009.

[15] G. Luna-Solano, M. A. Salgado-Cervantes, G. C. RodríguezJimenes, and M. A. García-Alvarado, "Optimization of brewer's yeast spray drying process," Journal of Food Engineering, vol. 68, no. 1, pp. 9-18, 2005.

[16] K. C. Patel and X. D. Chen, "Prediction of spray-dried product quality using two simple drying kinetics models," Journal of Food Process Engineering, vol. 28, no. 6, pp. 567-594, 2005.

[17] C. Palencia, J. Nava, E. Herman, G. C. Rodríquez-Jimenes, and M. A. García-Alvarado, "Spray drying dynamic modeling with a mechanistic model," Drying Technology, vol. 20, no. 3, pp. 569586, 2002.

[18] M. W. Woo, W. R. W. Daud, S. M. Tasirin, and M. Z. M. Talib, "Effect of wall surface properties at different drying kinetics on the deposition problem in spray drying," Drying Technology, vol. 26, no. 1, pp. 15-26, 2008.

[19] A. M. Telang and B. N. Thorat, "Optimization of process parameters for spray drying of fermented soy milk," Drying Technology, vol. 28, no. 12, pp. 1445-1456, 2010.

[20] J. Li, L. Zhang, and Y. Liu, "Optimization of extraction of natural pigment from purple sweet potato by response surface methodology and its stability," Journal of Chemistry, vol. 2013, Article ID 590512, 5 pages, 2013.

[21] S. V. Jangam and B. N. Thorat, "Optimization of spray drying of ginger extract,” Drying Technology, vol. 28, no. 12, pp. 1426-1434, 2010.

[22] J. Toneli, K. Park, A. Negreiros, and F. Murr, "Spray-drying process optimization of chicory root inulin," Drying Technology, vol. 28, no. 3, pp. 369-379, 2010.

[23] H. A. Al-Kahtani and B. H. Hassan, "Spray drying of roselle (Hibiscus sabdariffa L.) extract," Journal Food Science, vol. 55, no. 4, pp. 1073-1078, 1990.

[24] G. R. Chegini and B. Ghobadian, "Effect of spray-drying conditions on physical properties of orange juice powder," Drying Technology, vol. 23, no. 3, pp. 657-668, 2005.

[25] J. A. Grabowski, V.-D. Truong, and C. R. Daubert, "Spraydrying of amylase hydrolyzed sweetpotato puree and physicochemical properties of powder," Journal of Food Science, vol. 71, no. 5, pp. E209-E217, 2006.

[26] A. M. Goula, K. Adamopoulos, and N. A. Kazakis, "Influence of spray drying conditions on tomato powder properties," Drying Technology, vol. 22, no. 5, pp. 1129-1151, 2004.

[27] E. Ramirez, R. A. Martinez, and M. R. Fernandez, "Effect of sugar level and yeast strain on the quality of foaming ciber," Brazilian Journal of Food Technology, no. 5, pp. 89-95, 2005. 

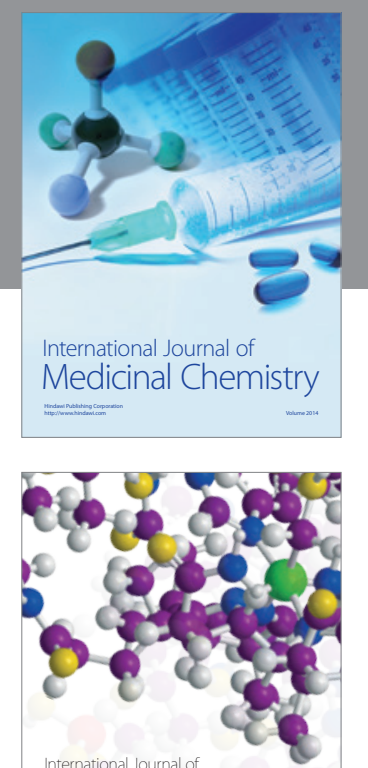

\section{Carbohydrate} Chemistry

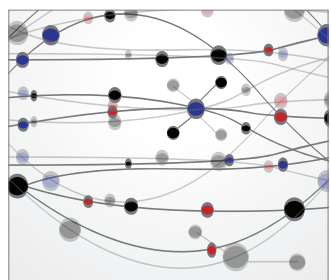

The Scientific World Journal
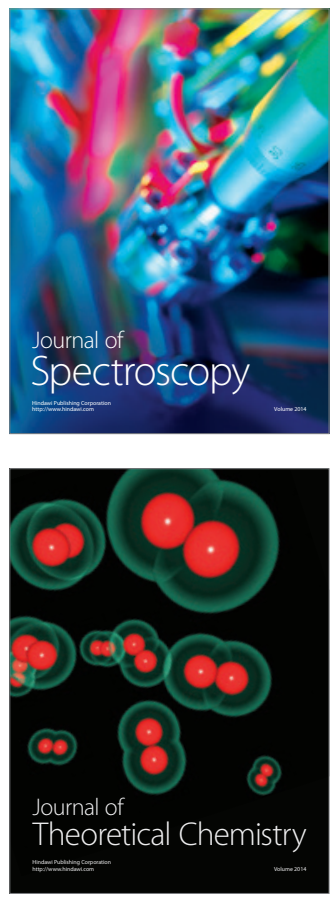
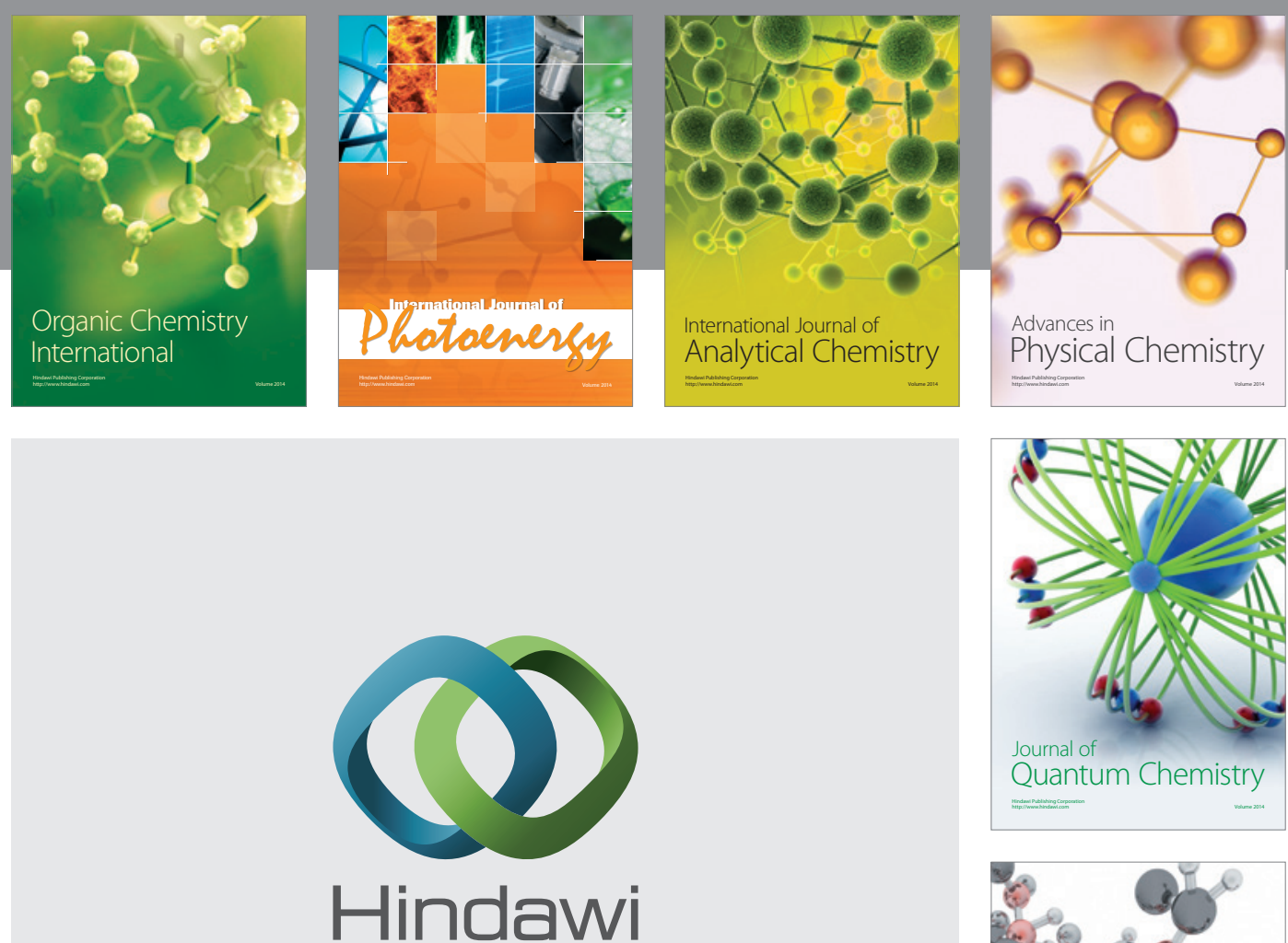

Submit your manuscripts at

http://www.hindawi.com

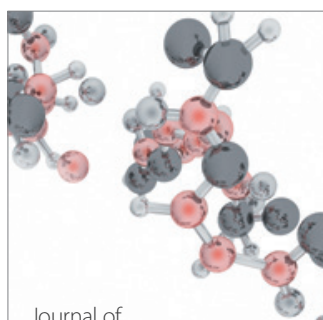

Analytical Methods

in Chemistry

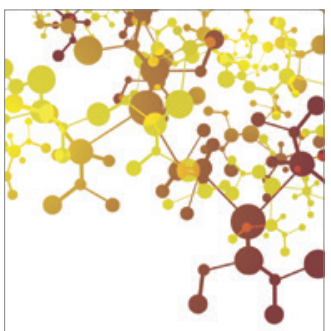

Journal of

Applied Chemistry

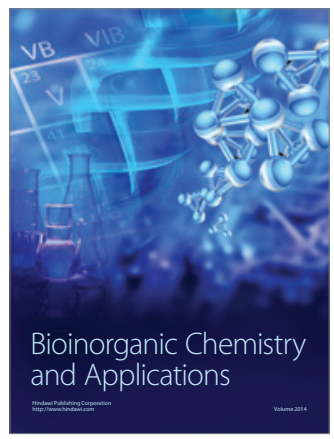

Inorganic Chemistry
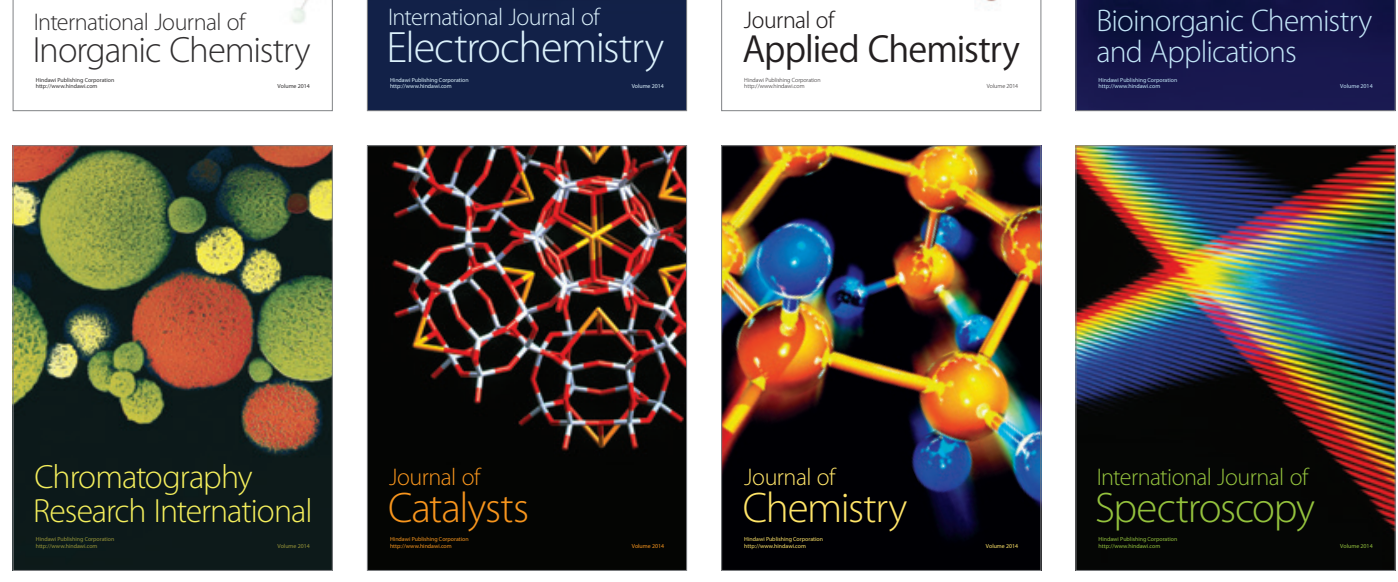